\title{
ANALISIS WACANA RETORIKA DAKWAH K.H. ABDULLAH GYMNASTIAR
}

\author{
Bahroni \\ Dosen Pendidikan Guru Madrasah Ibtidaiyah IAIN Salatiga \\ Bahronistainsala3@gmail.com
}

\begin{abstract}
Indonesia is big country which has biggest Muslim in the world so that dakwah activity is really strategic. Da'wah activities can not be avoided from press. the most well known da' $i$ in public are Abdullah Gymnastiar. This research was objected to describe the grammatical cohesion in their dakwah rhetoric. The procedure to analyze the data were as follow: (1) making into order the data that corresponds the problem answered; (2) Making into units the data based on its order according to the possibilities of category characteristics relation; (3) the interpreting the data score based on the problem that will be answered; (4) the evaluating the range of feasibility and completeness of data related to the problem stretch. The research result covered reference, substitution, elliptics, and conjunction.
\end{abstract}

Keywords: Rhetoric, Da'wah, Analysis of Discourse.

\begin{abstract}
Abstrak
Indonesia merupakan negara besar dengan muslim terbanyak di dunia, maka aktivitas dakwah merupakan hal yang sangat strategis. Aktivitas dakwah tidak luput dari liputan media massa,. Di antara da'i yang sangat dikenal oleh masyarakat adalah Abdullah Gymnastiar. Tujuan penelitian untuk mendeskripsikan wujud kohesi gramatikal retorika dakwah ketiga tokoh tersebut. Adapun langkah analisis data sebagai berikut: (1) pengurutan data sesuai dengan masalah yang akan dijawab; (2) pembentukan satuan-satuan data dalam setiap urutannya sesuai dengan kemungkinan hubungan ciri kategorinya; (3) interpretasi nilai data sesuai dengan masalah yan akan dijawab; (4) evaluasi tingkat kelayakan dan kelengkapan data dikaitkan dengan rentang masalahnya.wacana retorika dakwah tokoh ini mencakup referensi, substitusi, elipsis, dan konjungsi.
\end{abstract}

Kata Kunci: Retorika, Dakwah, Analisis Wacana. 
INJECT: Interdisciplinary Journal of Communication, Vol.1, No.1, Juni 2016: h. 119-141

\section{Pendahuluan}

Aktivitas mendakwahkan agama Islam-selanjutnya disebut dakwah-semakin berkembang di hampir semua lapisan masyarakat. Hal itu disebabkan oleh meningkatnya kebutuhan ruhani masyarakat yang senantiasa berkembang seiring dengan perkembangan kebutuhan jasmani atau duniawi mereka. Faktor lain yang mendukung perkembangan dakwah adalah fakta bahwa Indonesia merupakan satu negara besar dengan komunitas muslim terbanyak di dunia.

Semarak dakwah dan aktivitas-aktivitas keagamaan Islam yang lain, menurut Pudiyono (2008:247) merupakan hal yang sangat strategis. Oleh karena itu, aktivitas-aktivitas tersebut tidak luput dari liputan media massa, baik cetak maupun eletronik, baik offline maupun online. Hal ini dibuktikan dengan banyaknya majalah, radio, televisi, dan situs-situs di internet yang khusus menyebarluaskan pesan-pesan dakwah, bahkan sebagian besar televisi nasional maupun daerah yang tidak khusus untuk berdakwah pun, secara periodik menayangkan acara dengan konten dakwah.

Terkait dengan etika dakwah, Allah subhanahu wata'ala memerintahkan agar dakwah dilakukan dengan bijaksana, nasihat, dan diskusi yang baik. Dengan kata lain, dakwah itu hendaknya dilakukan dengan bahasa yang santun dan penuh empati sehingga dapat mencerahkan pikiran dan menyejukkan hati. Di antara da'i asli Indonesia yang sangat dikenal oleh masyarakat luas dan agaknya memiliki karakter sebagaimana dimaksud dalam al-Quran Surat an-Nahl ayat 125 tersebut adalah K.H. Abdullah Gymnastiar (Aa Gym).

Model dakwah yang dikembangkan oleh Aa Gym, agaknya berpedoman pada prinsip yang menyatakan bahwa mendakwahkan Islam itu sebaiknya memperkenalkan ajaran Islam yang dapat memberi jawaban atau solusi terhadap masalah kehidupan. Ini berarti pesan yang disampaikan dalam dakwah itu harus aktual, faktual, dan menonjolkan 
human interest-nya (Thaha, 1997:113). Di samping itu, dalam berdakwah harus memilih bahasa sedemikian rupa sehingga ummat tidak tersinggung tetapi justru dapat tersentuh hatinya (Thaha, 1997: 148). Di samping gaya retorika, hal lain yang menentukan efektifitas dakwah yaitu penguasaan massa, penguasaan persoalan yang dibahas, dan yang terpenting adalah keikhlasan pembicara. Apa yang dari hati akan sampai ke hati, sedangkan apa yang hanya keluar dari bibir biasanya hanya akan sampai ke telinga (Thaha, 1997:119).

Aa Gym memiliki komitmen yang sangat kuat pada penyebaran ajaran "Islam sebagai rahmatan lil'alamin" dengan tetap berpegang teguh pada prinsip tauhid dan akhlaqul karimah, kebersihan hati, keikhlasan, dan kebersamaan, termasuk dalam menyikapi setiap perbedaan. Aa Gym menyatakan, "Perbedaan adalah kenyataan. Bagaimana menyikapi perbedaan menuju ridha Allah ... itulah tantangannya" (Gymnastiar, 2005:63). "Saya ingin mengaplikasikan Islam sebagai rahmatan lil'alamin" (Gymnastiar, 2005:77). "Saya bercita-cita Daarut Tauhid sebagai miniatur Indonesia dengan menunjukkan wajah Islam yang indah, produktif, profesional, dan membawa rahmat bagi seisi alam" (Gymnastiar, 2005:97).

Aa Gym menyatakan bahwa manusia memiliki kesempatan untuk ma'rifatullah (kesanggupan mengenal Allah). Kesanggupan ini Allah karuniakan kepada manusia karena mereka memiliki akal dan nurani. Orang-orang yang hatinya hidup akan bisa mengenal dirinya sendiri, dan pada akhirnya akan berhasil pula mengenal Tuhannya (Gymnastiar, 2003:122). Selanjutnya Aa Gym menyatakan bahwa yang disebut sukses ialah ketika seseorang bisa berjumpa dengan Allah di akhirat nanti (Gymnastiar, 2005:97).

Terkenalnya Aa Gym merupakan bukti bahwa model dakwahnya humanis yang lebih menonjolkan ajaran Islam sebagai rahmatan lil'alamin sangat cocok dan dapat diterima oleh masyarakat muslim Indonesia yang memiliki keragaman etnis dan budaya. Oleh karena itu, model 
dakwah yang demikian itu perlu dikembangkan dan disebarluaskan lebih lanjut seiring dengan semakin meningkatnya kesadaran ummat akan pentingnya pemenuhan kebutuhan ruhani dan jasmani secara seimbang. Penyebarluasan, pemahaman, dan penghayatan secara mendalam terhadap model dakwah yang humanis itu, semakin penting artinya di tengah-tengah masyarakat Indonesia yang dewasa ini agaknya sedang mendapat gempuran yang sangat dahsyat dari pola hidup materialistik dan hedonistik. Dalam kondisi masyarakat Indonesia demikian ini, sentuhan dakwah yang humanis dan menyentuh nurani diharapkan dapat menyadarkan kembali kepada seluruh warga bangsa akan pentingnya pembangunan mental spiritual sebagaimana diamanatkan dalam lagu kebangsaan Indonesia Raya: 'Bangunlah jiwanya, bangunlah badannya untuk Indonesia Raya'.

Di antara cara yang dapat dilakukan untuk mengembangkan dan menyebarluaskan konsep tertentu adalah melalui kegiatan penelitian. Oleh karena itu, dalam rangka mengembangkan, menyebarluaskan, memahami, dan menghayati secara mendalam model dakwah yang agaknya sangat cocok dengan karakteristik masyarakat Indonesia yang majemuk itu, maka penelitian tentang "Analisis Wacana Retorika Dakwah K.H. Abdullah Gymnastiar" adalah penting untuk dilakukan. Hal itu demikian, karena dewasa ini pemahaman tentang wacana tidak bisa ditinggalkan oleh siapa saja yang ingin menguasai informasi. Wacana sebagai dasar dalam pemahaman teks sangat diperlukan oleh masyarakat dalam berkomunikasi dengan informasi yang utuh. Teks tersususn dari unsur-unsur yang saling terkait sehingga terciptalah satu kesatuan yang utuh yang membentuk wacana. Dengan demikian, melalui penelitian analisis wacana ini diharapkan pemahaman terhadap retorika dakwah Aa Gym tersebut menjadi lebih utuh. 


\section{Permasalahan}

Dari uraian di atas fokus permasalahan adalah sebagai berikut (1) bagaimanakah wujud kohesi gramatikal retorika dakwah Aa Gym?, dan (2) bagaimanakah wujud kohesi leksikal retorika dakwah Aa Gym? Adapun tujuan penelitian ini adalah untuk (1) mendeskripsikan dan menjelaskan wujud kohesi gramatikal retorika dakwah Aa Gym, dan (2) mendeskripsikan dan menjelaskan wujud kohesi leksikal retorika dakwah Aa Gym.

\section{Retorika Dakwah}

Seseorang yang ingin menjadi pembicara yang handal harus mampu memahami situsi dan kondisi mitra tuturnya serta mampu beradaptasi di mana dan dalam situasai bagaimana ia sedang berbicara. Untuk dapat dapat menjadi pembicara yang demikian itu, maka pemahaman tentang retorika menjadi penting.

Retorika atau dalam bahasa Inggris rhetoric berasal dari bahasa Latin rhetorica yang berarti ilmu bicara. Termasuk dalam cakupan pengertian retorika adalah seni berbicara, kemahiran dan kelancaran berbicara, kemampuan memproduksi gagasan, dan mensosialisasikannya sehingga mampu mempengaruhi audience (http://indramukhtaroji. blogspot.com/retorika, diakses pada pada 26 Mei 2015). Retotika adalah seni berbicara atau kemampuan merangkai kata-kata dengan maksud agar pendengar mudah memahami makna pesan yang disampaikannya. Selanjutnya, pengertian dakwah. Secara etimologis, dakwah berasal dari bahasa Arab yang berarti panggilan, seruan, atau ajakan kepada sesuatu (Suminto, 1984:53). Adapun secara terminologis, dakwah adalah mengajak, membimbing, dan memimpin orang yang belum mengerti atau sesat jalannya dari agama yang benar untuk dialihkan ke jalan ketaatan kepada Allah, menyuruh orang berbuat baik dan melarang berbuat buruk agar mendapat kebahagiaan di dunia dan akhirat (Syaikh Abdullah 
Ba'alawi dalam Saputra, 2002:2).

Senada dengan itu, Faridl (1982:134) menyatakan bahwa dakwah merupakan seruan kepada manusia untuk melaksanakan segala perintah Allah dan menjauhi segala yang dilarang-Nya. Dakwah dalam pengertian tersebut, adalah searti atau berdekatan arti atau mencakup pengertian: (1) tabligh yakni menyampaikan ajaran Allah, (2) jihad yakni berjuang menegakkan agama Allah, (3) ishlah yakni menyelesaikan persoalan sesuai dengan ajaran Allah, (4) khutbah yakni berpidato tentang ajaran Allah, (5) taushiyyah yakni berwasiat atau memberi nasihat, dan (6) amarma'ruf nahi munkar yakni memerintahkan kepada kebaikan dan melarang dari keburukan.

Kedudukan hukum dakwah adalah fardhu 'ain, yaitu kewajiban setiap individu muslim. Allah memerintahkan agar setiap muslim berusaha mengubah kemungkaran yang diketahuinya. Oleh karena itu, alQuran Surat al-Imran ayat 104 dan surat at-Taubah ayat 122 menjelaskan kepada kaum Muslim diperintahkan agar ada sekelompok Muslim yang menekuni ajaran Islam secara khusus untuk disampaikan dan diajarkan kepada orang lain.

Berdasarkan pengertian retorika dan dakwah di atas, maka retorika dakwah dapat diartikan sebagai ketrampilan menyampaikan ajaran Islam secara lisan guna memberikan pemahaman yang benar kepada kaum muslimin agar mereka dapat dengan mudah menerima seruan dakwah yang karenanya pemahaman dan prilakunya dapat berubah menjadi lebih Islami.

Seorang pendakwah perlu mempelajari retorika dakwah, agar ceramahnya dapat berlangsung dengan baik, mencerahkan pikiran dan dan menyentuh hati jamaah. Dengan demikian, di samping penguasaan konsepsi Islam dan pengamalannya, keberhasilan dakwah juga sangat ditentukan oleh kemampuan komunikasi antara sang da'i dengan jama'ah yang menjadi objek dakwah. 


\section{Metode Penelitian}

Penelitian ini menggunakan pendekatan kualitatif-deskriptif, yakni bertujuan untuk mengungkapkan berbagai informasi kualitatif dengan pendeskripsian yang teliti dan penuh nuansa untuk menggambarkan secara cermat sifat-sifat suatu hal, keadaan, fenomena, dan tidak terbatas pada pengumpulan data, tetapi meliputi analisis dan interpretasi data tersebut (Sutopo, 2002:111). Data penelitian kebahasaan adalah fenomena lingual khusus yang berkaitan langsung dengan masalah penelitian (Sudaryanto, 2002:5-6).

Data penelitian ini berupa satuan-satuan lingual yang membentuk kohesi gramatikal dan leksikal ditambah dengan faktor-faktor situasi dan latar belakang sosiokultural yang terdapat di luar teks. Sumber data dalam penelitian berupa rekaman ceramah empat da'i, yakni Zainuddin, Aa Gym, Arifin, dan YM yang tersimpan dalam kaset dan alat-alat penyimpan yang lain, termasuk yang terdapat di media online seperti Youtube, serta dokumen-dokumen yang memuat ceramah empat da'i tersebut. Data dalam penelitian ini akan dikumpulkan dengan menggunakan teknik rekam, simak, dan catat. Di samping itu, juga akan digunakan teknik pustaka, yakni teknik pengambilan data dari berbagai sumber tertulis beserta konteks lingual yang mendukung analisis data. Berbagai tulisan dipilih yang mencerminkan pemakaian potensi bahasa yang khas (Subroto,1992:42).

Agar data yang diperoleh dapat dipertanggung jawabkan secara ilmiah dan dapat menjadi landasan dalam penarikan kesimpulan, maka sebelum informasi dijadikan data penelitian perlu dicermati validitas dan reliabiltasnya. Untuk menjamin keabsahan dan kredibilitas data penelitian, digunakan teknik trianggulasi, yang lazim dipakai dalam penelitian kualitatif.

Teknik pengolahan dan analisis data dilakukan langkah-langkah sebagai berikut: (1) pengurutan data sesuai dengan masalah yang akan 
dijawab; (2) pembentukan satuan-satuan data dalam stiap urutannya sesuai dengan kemungkinan hubungan cici kategorinya; (3) interpretasi nilai data sesuai dengan masalah yan akan dijawab; (4) evaluasi tingkat kelayaan dan kelengkapan data dikaitkan dengan rentang masalahnya (Aminuddin, 1995:67).

\section{Wujud Kohesi Gramatikal Retorika Dakwah Aa Gym}

Wujud kohesi gramatikal mencakup (1) referensi, (2) substitusi, (3) elipsis, dan (4) konjungsi. Referensi merupakan salah satu jenis kohesi gramatikal yang berupa satuan lingual tertentu yang menunjuk satuan lingual lain yang mendahului atau mengikutinya. Substitusi merupakan salah satu kohesi gramatikal yang berupa penggantian satuan lingual tertentu (yang telah disebut) dengan satuan lingual lain. Elipsis adalah salah satu jenis kohesi gramatikal yang berupa penghilangan unsur (konstituen) tertentu yang telah disebutkan. Konjungsi merupakan salah satu jenis kohesi gramatikal yang dilakukan dengan cara menghubungkan unsur yang satu dengan yang lain. Makna konjungsi bermacam-macam tergantung hubungan semantik yang ditimbulkan akibat pertemuan kalimat yang satu dengan yang lain dalam wacana (Ramlan, 1993:28).

Wujud kohesi gramatikal dalam teks ceramah Aa Gym berikut ini bersumber dari http://farischan.dagdigdug.com/?cat=66043 diakses tanggal 03, November 2015.

\section{Referensi}

Referensi sebagai alat kepaduan antarkalimat dalam teks ceramah Aa Gym dapat dilihat dalam contoh berikut ini.

(1) Orang tenang akan bisa menerima informasi lebih banyak, hingga dia bisa lebih memahami. Sedangkan orang yang emosional pendek kemampuan memahaminya, akibatnya kalau merespon akan tidak bagus karena keterbatasan pemahamannya. Ketenangan pun akan 
membawa kewibawaan, atau karisma tersendiri bagi pemiliknya. Ia akan disegani oleh teman dan lingkungannya.

(2) Sebaliknya, orang yang overacting tidak akan memiliki kharisma. Terutama, kepada para calon pemimpin dalam skala apapun, ia harus berlatih mengendalikan diri, tetap tenang dalam kondisi bagaimanapun sulitnya.

(3) Dan, tenang bukan berarti lamban. Nabi Muhammad SAW adalah manusia paling tenang, tetapi berjalannya sangat gesit. Karena ketenangan tidak ada kaitannya dengan waktu, melainkan dengan pengendalian diri, artinya dia tetap gesit, tangkas tidak ada gurau berlebih, atau berteriak-teriak.

(4) Namun, ketenangan harus diupayakan agar tidak berujung menjadi sombong. Cirinya adalah ketika ia tidak peduli kepada orang lain. Dia diam tapi tidak mau mendengarkan. Malah mungkin asyik melakukan kegiatan yang lain (saat orang lain berbicara padanya). Atau, ada orang yang diam karena dia tengah memikirkan bantahan kepada orang lain, bukannya mengemas manfaat dari pembicaraan yang didengarnya.

(5) Apa itu manusia wajib? Manusia wajib ditandai jikalau adanya sangat dirindukan, sangat bermanfaat, bahkan perilakunya membuat hati orang di sekitarnya tercuri. Tanda-tanda yang nampak dari seorang 'manusia wajib', di antaranya dia seorang pemalu yang jarang mengganggu orang lain, sehingga orang lain merasa aman darinya. Perilaku kesehariannya lebih banyak kebaikannya. Ucapannya senantiasa terpelihara, ia hemat betul kata-katanya, sehingga lebih banyak berbuat daripada hanya berbicara.

Pada data (1) tersebut, dia dan ia merupakan referensi persona ketiga tunggal yang menunjuk frasa sebelumnya, yaitu orang tenang, data (2) ia menunjuk pada frasa orang yang overacting, data (3) dia menunjuk pada Nabi Muhammad SAW (manusia paling tenang), data (4) dia dan ia 
menunjuk pada frasa (orang) sombong, dan data (5) dia dan ia menunjuk pada frasa manusia wajib.

\section{Substitusi}

Substitusi sebagai penanda kohesi gramatikal antarkalimat dapat berfungsi untuk menghilangkan kemonotonan, sebagaimana dapat dilihat dalam contoh-contoh berikut.

(6) Ucapannya senantiasa terpelihara, ia hemat betulkata-katanya, sehingga lebih banyak berbuat daripada hanya berbicara.

(7) Keramahannya pun benar-benar menjadi penyejuk bagi hati yang sedang membara. Jikalau saja orang berakhlak mulia ini tidak ada, maka siapapun akan merasa kehilangan, akan terasa ada sesuatu yang kosong di rongga kalbu ini.

(8) Dan informasi itu sendiri tidak boleh diambil hanya dari satu pihak. Kita harus belajar dari kedua belah pihak, baru mengambil keputusan. Dan yang harus kita sadari adalah tidak ada keputusan tanpa resiko, semua keputusan ada resikonya. Kita hanya perlu menghitung resiko yang paling minimal.

(9) Sungguh beruntung bagi siapapun yang dikaruniai Allah kepekaan untuk mengamalkan aneka pernik peluang kebaikan yang diperlihatkan Allah kepadanya. Beruntung pula orang yang dititipi Allah aneka potensi kelebihan oleh-Nya, dan dikaruniakan pula kesanggupan memanfaatkannya untuk sebanyak-banyaknya umat manusia. Karena ternyata derajat kemuliaan seseorang dapat dilihat dari sejauhmana dirinya punya nilai manfaat bagi orang lain.

(10)Sedangkan orang yang mubah ada dan tidak adanya tidak berpengaruh. Di kantor kerja atau bolos sama saja. Seorang pemuda yang ketika ada di rumah keadaan menjadi berantakan, dan kalau tidak adapun tetap berantakan. Inilah pemuda yang mubah. Ada dan tiadanya tidak membawa manfaat, dan tidak juga membawa mudharat. 
Pada data (6) tersebut, satuan lingual hemat betul kata-katanya disubstitusi dengan satuan lingual lebih banyak berbuat daripada hanya berbicara, data (7) satuan lingual merasa kehilangan disubstitusi dengan satuan lingual terasa ada sesuatu yang kosong, data (8) satuan lingual tidak boleh diambil hanya dari satu pihak pada kalimat pertama disubstitusi dengan satuan lingual dari kedua belah pihak pada satuan lingual kedua, data (9) satuan lingual memanfaatkannya untuk sebanyak-banyaknya umat manusia pada kalimat kedua disubstitusi dengan satuan lingual punya nilai manfaat bagi orang lain pada kalimat ketiga, data (10) satuan lingual orang yang mubah pada kalimat pertama disubstitusi dengan satuan lingual Ada dan tiadanya tidak membawa manfaat, dan tidak juga membawa mudharat pada kalimat terakhir.

\section{Elipsis (ø)}

Elipsis sebagai penanda kohesi gramatikal dalam teks ceramah Aa Gym dapat dilihat dalam contoh berikut.

(11) Adapun orang yang makruh, keberadaannya justru membawa mudharat dan kalau dia tidak ada tidak berpengaruh. Artinya, kalau dia datang ke suatu tempat maka orang merasa bosan atau tidak senang (ø).

(12) Seorang anak yang makruh, kalau pulang sekolah justru masalah pada bermunculan, dan kalau (ø) tidak pulang suasana malah menjadi aman tentram.

(13) Masya Allah, tidak ada salahnya kita merenung sejenak, tanyakan pada diri ini apakah kita ini anak yang menguntungkan orang tua atau malah hanya jadi benalu saja (ø).

(14) Kadang aneh kita ini, ketika duduk di taman nan hijau, entah sadar atau tidak kita cabuti rumput atau daun-daunan yang ada (ø) tanpa alasan yang jelas.

(15) Kejadian lain adalah ketika seorang hamba yang shalih dihampiri seekor singa yang mengaum-ngaum seakan hendak menerkamnya. 
Tentu saja semua orang yang melihat kejadian ini berlari ketakutan $(\varnothing)$.

Pada data (11) yang dielipskan satuan lingual kepada orang yang makruh, data (12) yang dielipskan satuan lingual anak yang makruh, data (13) yang dielipskan satuan lingual bagi orang tua, data (14) yang dielipskan satuan lingual di taman nan hijau, dan data (15) yang dielipskan satuan lingual kepada seekor singa.

\section{Konjungsi}

Konjungsi yang digunakan untuk menghubungkan kalimat satu dengan kalimat lain dalam teks ceramah Aa Gym adalah sebagai berikut. (16) Seraya mengajak berbicara layaknya pada makhluk yang bisa diajak bicara, "Mau apa kesini? Kalau tidak ada kewajiban dari Allah dan hanya untuk mengganggu masyarakat, alangkah baiknya engkau pergi", maka pergilah singa itu, subhanallah. Demikianlah, orang yang takutnya hanya kepada Allah, makhluk pun tunduk kepadanya.

(17) Semoga Allah memberi kemampuan kepada kita untuk membaca potensi yang telah Allah berikan. Menggali dan mengembangkan diri kita dengan baik sehingga hidup yang sekali-kalinya ini tidak menjadi beban bagi orang lain, bahkan hidup terhormat karena bisa meringankan beban orang lain.

(18) Sebagaimana sabda Rasulullah SAW, sebaik-baik manusia adalah manusia yang paling banyak manfaatnya. Benar, dalam hidup ini kita pasti membutuhkan orang lain. Itu pasti! Tetapi menikmati hidup dengan membebani orang lain adalah hidup yang tidak mulia.

(19) Orang yang berharap pertolongan kepada manusia lebih rendah posisinya dibanding dengan orang yang memiliki kemampuan menolong banyak orang.

(20) Kita diberi kemampuan oleh Allah untuk mengubah nasib kita. Berarti, kemampuan kita untuk mandiri dalam mengarungi hidup 
ini, merupakan kunci yang diberikan oleh Allah untuk sukses dunia dan insya Allah akhirat kelak.

Pada data (16) terdapat konjungsi demikianlah untuk merangkai kalimat-kalimat sebelumnya dengan kalimat sesudahnya. Konjungsi ini digunakan untuk menegaskan gagasan-gagasan yang terdapat pada kalimat-kalimat sebelumnya sehingga gagasan intinya semakin mudah dipahami oleh pembaca. Pada data (17) terdapat konjungsi bahkan yang berfungsi untuk menegaskan gagasan-gagasan yang terdapat pada kalimatkalimat sebelumnya dengan cara menambahkan nilai tertentu yang relevan dengan gagasan-gagasan sebelumnya. Pada data (18) terdapat dua konjungsi yaitu benar dan tetapi. Yang pertama untuk menegaskan gagasan sebelumnya dengan menambahkan pernyataan sesudahnya, dan yang kedua untuk member batasan agar gagasan sebelumnya tidak salah arah atau menyimpang. Pada data (19) terdapat konjungsi dibanding untuk membandingkan pernyataan sebelum dan sesudahnya. Adapun pada data (20) terdapat konjungsi berarti yang berfungsi untuk menegaskan atau menyimpulkan pernyataan pada kalimat sebelumnya.

\section{Wujud Kohesi Leksikal Retorika Dakwah Aa Gym}

Kohesi leksikal tidak berkaitan dengan hubungan gramatikal dan hububungan sematik. Kohesi leksikan ini hanya berkaitan dengan hubungan yang didasarkan pada pemakaian kata. Terdapat sejumlah peranti kohesi leksikal untuk mewujudkan keututuhan suatu wacana, yaitu (1) repetisi (pengulangan), (2) sinonimi (persamaan kata), (3) antonimi (lawan kata), (4) hiponimi (hubungan atas bawah), (5) kolokasi (sanding kata), dan (6) ekuivalensi (kesepadanan).

\section{Repetisi}

Contoh-contoh kohesi leksikal jenis repetisi banyak digunakan oleh Aa Gym dalam teks ceramahnya (https://m.youtube.com/watch 
diakses pada 16 Oktober 2015), dapat dilihat pada contoh-contoh berikut.

(21) Kita sangat ingin keluarga kita menjadi orang orang yang sholeh, kita ingin menjadikan anak-anak patuh dan sholeh, kita ingin tetangga yang baik, kita ingin negara kita menjadi baik.

(22) Hebatnya kata-kata yang tak sebanding dengan perilaku kita, maka kita sendiri yang menghancurkan kata-kata kita.

(23) Orang yang memikirkan hal yang besar tapi yang kecil saja dia tidak sanggup melakukan hanya mimpi di siang bolong!, dan mulailah saat ini. Mengapa? karena besok belum tentu hidup, lusa belum tentu ada, waktu kita adalah waktu saat ini.

(24) Allah menyaksikan kalau perubahan kita, kita lakukan dengan ikhlas. Artinya bukan karena pujian, bukan untuk kekaguman orang, bukan untuk mendapatkan penghargaan.

(25) Keberuntungan tidak diukur oleh harta, gelar pangkat, maupun jabatan. Keberuntungan seseorang di ukur dari kesanggupannya memperbaiki diri dari waktu ke waktu.

(26) Mulailah dari diri sendiri, mulailah dari hal yang kecil, mulailah saat ini. Lilahita'ala.

Pada data (21) terdapat jenis repetisi anáfora yakni berwujud perulangan kata pertama pada tiap baris atau kalimat berikutnya yaitu berupa kata kita. Pada data (22) terdapat jenis repetisi mesodiplosis yakni repetisi di tengah baris-baris atau kalimat-kalimat yaitu berupa reduplikasi kata-kata. Pada data (23) juga terdapat jenis repetisi mesodiplosis yakni repetisi di tengah baris-baris atau kalimat-kalimat yaitu berupa frasa belum tentu. Pada data (24) juga terdapat jenis repetisi epizeuksis yakni repetisi yang bersifat langsung, artinya kata yang dipentingkan diulang beberapa kali berturut-turut. Dalam hal ini yang diulang adalah kata bukan. Pada data (25) terdapat jenis repetisi anáfora yakni berwujud perulangan kata pertama pada tiap baris atau kalimat berikutnya yaitu kata keberuntungan. 
Adapun pada data (26) juga terdapat jenis repetisi epizeuksis yakni repetisi yang bersifat langsung, artinya kata yang dipentingkan diulang beberapa kali berturut-turut. Dalam hal ini yang diulang adalah verba mulailah.

\section{Sinonimi}

Kohesi leksikal jenis ini banyak digunakan oleh Aa Gym dalam teks ceramahnya, sebagaimana dapat dilihat pada contoh-contoh berikut. (27) Allah tau sakinah itu bukan datang dari rayuan, pujian, penampilan, kosmetik. Sakinah itu datang dari Allah bagi orang yang hatinya bersih.

(28) Kalau Rasulullah menyebut istrinya humairah, karena memang agak kemerah-merahan.

(29) Bisnis itu ibadah. Bisnis itu untuk taat ke Allah, bisnis itu untuk taat ke Rasul, bisnis itu untuk jihad. InsyaAllah tenang.

(30) Wahai Allah Yang Maha Agung, jadikan saat ini saat mustajab doa, Ya Rab. Mudah bagimu mengabulkan apapun, tiada Tuhan selain Engkau yang menggenggam langit dan bumi Yang Maha Agung, Yang Maha Baik, Yang Maha Penyayang, Yang Maha Mengerti, Yang tidak pernah mengecewakan orang-orang hina seperti kami, yang tidak pernah membiarkan orang-orang kotor seperti kami.

(31) Semoga Allah memberi kemampuan kepada kita untuk membaca potensi yang telah Allah berikan. Menggali dan mengembangkan diri kita dengan baik sehingga hidup yang sekali-kalinya ini tidak menjadi beban bagi orang lain, bahkan hidup terhormat karena bisa meringankan beban orang lain.

Dalam konteks kalimat pada data (27) kata penampilan bersinonim kosmetik. Dalam konteks kalimat pada data (28) kata humairah bersinonim bersinonim dengan frasa agak kemerah-merahan. Dalam konteks kalimat pada data (29) kata ibadah bersinonim dengan frasa taat kepada Allah. Dalam konteks kalimat pada data (30) kata hina bersinonim dengan kata 
INJECT: Interdisciplinary Journal of Communication, Vol.1, No.1, Juni 2016: h. 119-141

kotor. Adapun dalam konteks kalimat pada data (31) frasa tidak menjadi beban bersinonim dengan kalusa meringankan beban.

\section{Antonimi}

Kohesi leksikal jenis ini banyak digunakan oleh Aa Gym dalam teks ceramahnya, sebagaimana dapat dilihat pada contoh-contoh berikut.

(32) Kita tidak disuruh mencari rezeki, kita disuruh menjemput rezeki. Kalau mencari antara ada dan tiada. Tapi, kalau menjemput sudah pasti ada.

(33) Allah menciptakan yang halal, Allah menciptakan yang haram.

(34) Satu angkatan di sekolah umur sama, rezeki beda-beda.

(35) Puji caci biasa saja, sehat sakit hanya episode

(36) Ampuni kami lebih banyak lupa daripada ingat kepada-Mu. Lebih banyak ragu daripada yakin pada-Mu.

(37) Orang-orang yang terlatih menghadapi masalah sendiri akan berbeda semangatnya dalam mengarungi hidup ini dibanding dengan orang yang selalu bersandar kepada orang lain.

(38) Allah tidak akan menyia-nyiakan orang yang sedekah, tidak akan berkurang harta denga sedekah, hanya kita berat mengeluarkan uang, sepuluh ribu di mall, dengan sepuluh ribu di masjid, beda, di mall terasa kecil sekali sepuluh ribu tapi di masjid terasa besar sedekah sepuluh ribu.

(39) Itulah budaya setan yang membuat kita kikir, saya berani bersumpah demi Allah, kalau kita gemar bersyukur pasti Allah akan tambahkan. Jangan pernah takut oleh rezeki yang belum ada, tapi takutlah tidak mensyukuri rezeki yang sudah ada.

Pada data (32) kata ada berantonin atau beroposisi tiada. Oposisi antara ada dengan tiada bersifat mutlak. Dalam oposisi mutlak terdapat pertentangan makna secara mutlak, misalnya antara kata diam dan gerak, 
antara kata hidup dan mati terdapat batas yang mutlak, sebab sesuatu yang diam tentu tidak bergerak dan sesuatu yang bergerak tentu tidak diam. Begitu pula, sesuatu yang hidup tentu tidak mati dan sesuatu yang mati tentu tidak hidup. Kedua proses ini tidak dapat berlangsung bersamaan, tetapi secara bergantian. Pada data (33) kata halal beroposisi dengan haram. Oposisi antara halal dengan haram juga disebut oposisi mutlak meskipun di anatara keduanya ada status yang disebut syubhat.

Pada data (34) kata sama beroposisi dengan beda. Oposisi antara sama dengan beda disebut oposisi kutub. Dalam oposisi kutub ini pertentangan maknanya tidak bersifat mutlak, tetapi bersifat gradasi, yaitu adanya tingkat-tingkat makna. Misalnya, kata panas dan dingin, kata kaya dan miskin, kata besar dan kecil, serta kata tinggi dan rendah. Kata-kata yang termasuk dalam kategori oposisi kutub ini bersifat relatif, karena sulit ditentukan batasnya secara mutlak. Batasnya dapat bergeser-geser, tidak tetap pada satu titik. Dalam oposisi jenis ini dimungkinkan kata yang beroposisi itu dapat bersandingan dengan kata-kata seperti agak dan sangat: agak sama, sangat sama, agak beda, sangat beda. Pada data (35) juga terdapat jenis oposisi kutub, yakni kata puji beroposisi dengan caci dan kata sehat beroposisi dengan sakit. Begitu pula pada data (36), oposisi antara lupa dengan ingat dan ragu dengan yakin adalah oposisi kutub. Oposisi pada data (37) yakni antara satuan lingual menghadapi masalah sendiri dengan satuan lingual selalu bersandar kepada orang lain juga merupakan oposisi kutub. Oposisi kutub juga ditunjukkan oleh kata kecil dan besar yang terdapat pada data (38). Adapun pada data (39) terdapat oposisi mutlak, yakni kata belum yang beroposisi dengan sudah.

\section{Hiponimi}

Kohesi leksikal jenis ini banyak digunakan oleh Aa Gym dalam teks ceramahnya, sebagaimana dapat dilihat pada contoh-contoh berikut. (40) Maaf sodaraku sekalian kalau tidak bisa dengan harta, dengan raut 
muka yang ramah itu sedekah, sedekah itu luas sekali, sedekah dengan perhatian, ada orang yang sedang pusing kita mau mendengarkan walaupun kita tidak bisa memberi solusi, mendengarkan saja sedekah, karena ada orang yang hanya butuh didengarkan walaupun saya belum bisa mengamalkan ini sepenuhnya karena ada yang bukan. Saya akan menceritakan riwayat hidup saya seluruhnya, tak bisa separuh separuh. Ya tolong aja dikorting. Orang curhat kita mendengarkan iya pun sedekah, sedekah waktu sedekah perhatian, kalau tidak bisa sedekah dengan itu ada lagi potensi lain dengan tenaga, nyapu. Pernah dengar ada seorang santri yang dia sedekahnya adalah mencucikan mobil? CeramahAagymtentangsedekahhttp:// youtu.be/XaF4Tu6ptwl, diakses pada tanggal 07 Desember 2015.

(41) Hati-hati untuk orang yang amal ibadahnya temporal, sebab mungkin itu adalah tanda-tanda ikhlasnya belum sempurna. Sebab ibadah yang dikerjakan dengan temporal tidak ada lain, ukurannya ialah urusan dunia. Amal tersebut hanya dikerjakan jika sedang butuh, lagi dilanda musibah, atau lagi ada ujian kesusahan. Tidak demikian halnya manakala pertolongan dari Allah datang, datang kesenangan, maka kemampuannya bersenang-senangnya bersama Allah malah menghilang.

(42) Kalau Allah sayang kepada kita Allah akan mengingatkan kita dengan berbagai kejadian, dompet hilang lah, sakit, di PHK, uang habis, pokoknya kalau kita disayang Allah, kita akan diingatkan dengan berbagai kepahitan sebagai jalan "kafarah" nya.

(43) Tobat saja, seperti nabi yunus, 3 kegelapan gelapnya malam, gelapnya laut dan gelapnya perut ikan.

(44) Yakk, alhamdulillah hujan, Allah lagi punya rencana sendiri. Airnya sama, tanahnya sama, nanti yang jadi pohon beda-beda. Ada rumput jepang, ada rumput gajah, ada rumput liar, ada pohon, ada selada, ada seledri, macem-macem. Padahal airnya sama, tanahnya sama, 
ada bunga warnanya beda-beda, bentuknya beda-beda, padahal airnya sama, harumnya beda-beda. Ada yang harum jengkol, namanya pohon jengkol, nanti jadi buah, macem-macem. Ada kulit duren, tajem-tajem, siapa yang ngarang ini. Di dalamnya legit, enak, bijinya keras. Ada salak, sekelilingnya duri, bungkusnya bagus, ada selaput yang mulus, apalagi salak, salak apa yang enak? Salak pondoh, didalamnya ada lumutan. Bijinya keras, siapa yang naruh disana. Belum lagi pisang mulus, bungkus kita kurang bagus, bungkus orang mah gak jelas, dikupas di dalamnya mulus, airnya sama, tanahnya

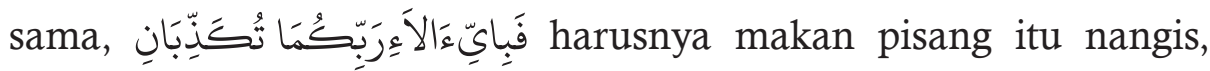
kenapa? Karena Cuma satu. Saya ada yang ngirimi buah-buahan, aduh ya Allah, bagus-bagus buahnya, liat aja udah takjub, takjub kepada yang mendesain, mengatur kombinasi warna, meletakkan kulit, bulu-bulu halusnya, masya Allah. Biar nggak usah pengenlah, biar saya aja yang menghabiskan. Masya Allah, terimakasih. Tidak ada pertanyaan lain. Senang tidak ilmu tauhid ini?

Pada data (40) satuan lingual harta, raut muka, perhatian, mendengarkan berhiponim terhadap kata sedekah (hipernim). Pada data (41) satuan lingual jika sedang butuh, lagi dilanda musibah, dan lagi ada ujian kesusahan berhiponim terhadap kata temporal (hipernim). Pada data (42) satuan lingual dompet hilang lah, sakit, di PHK, dan uang habis berhiponim terhadap kata kejadian (hipernim). Pada data (43) satuan lingual gelapnya malam, gelapnya laut, dan gelapnya perut ikan berhiponim terhadap kata kegelapan (hipernim). Adapun pada data (44) satuan lingual pohon jengkol, pohon duren, pohon salak, dan pohon pisang berhiponim terhadap kata pohon (hipernim).

\section{Kolokasi}

Kolokasi merupakan alat kohesi leksikal berupa asosiasi tertentu dalam menggunakan pilihan kata dan cenderung digunakan secara berdampingan. Kolokasi pada teks ceramah Aa Gym adalah sebagai 
INJECT: Interdisciplinary Journal of Communication, Vol.1, No.1, Juni 2016: h. 119-141

berikut.

(45) Allah menciptakan yang halal, allah menciptakan yang haram, Allah ciptakan yang mubah, Allah ciptakan yang makruh, ..... Bahkan yang jadi ibadah haqqul yaqiin. ada Allah ciptakan babi, Allah ciptakan khamer (minuman keras), Allah juga ciptakan yg menimbulkan baubauan, Allah juga ciptakan rokok yang jelas meracuni tubuh.

(46) Orang kafirin, dhalimin, munafiqin, pelacur, pezina, orang-orang yang jahat, nista perbuatannya, kasih rezeki ini, karena tidak ada harganya.

(47) Apalagi makin tua makin dibatasi. Diberi oleh Allah penyakit asam urat, tidak bisa makan buah-buahan dan sayur-sayuran, diberi oleh Allah kolesterol diberi oleh Allah penyakit gula, diberi lagi asma, diberi sariawan.

(48) Tinggal jadi orang yang bener saja, hatinya tulus, ibadahnya bagus, hidupnya lurus, ikhtiyarnya serius, obatnya terus-menerus, Allah yang mengurus.

(49) Makanya orang-orang yang susah, itu pasti bukan gak ada rezekinya. Tapi enggak ada keyakinan, enggak ada kesungguhan, enggak ada keikhlasan.

Pada data (45) kolokasi atau sanding kata terjadi pada halal, haram, mubah, dan makruh yang merupakan lingkungan hukum Islam yang lima (al-ahkam al-khamsah). Selain itu, satuan lingual babi, khamer, dan rokok merupakan kolokasi contoh-contoh dari lingkungan hukum Islam tersebut. Data (46) kolokasi terjadi pada kafirin, dhalimin, dan munafiqin yang merupakan lingkungan status orang-orang yang tidak taat pada aturan Allah, misalnya pelacur, pezina, orang-orang yang jahat, dan nista perbuatannya. Data (47) kolokasi terjadi pada asam urat, kolesterol, penyakit gula, asma, dan sariawan yang merupakan lingkungan penyakit. Data (48) kolokasi terjadi pada orang yang bener, hatinya tulus, ibadahnya bagus, 
hidupnya lurus, dan ikhtiyarnya serius yang merupakan lingkungan orangorang yang baik. Adapun pada data (49) kolokasi terjadi pada enggak ada keyakinan, enggak ada kesungguhan, enggak ada keikhlasan yang merupakan lingkungan orang-orang yang tidak baik.

\section{Ekuivalensi}

Ekuivalensi adalah kesepadanan paradigm, yaitu sejumlah hasil proses afiksasi dengan morfem asal yang sama. Kohesi jenis ini pun dijumpai dalam teks ceramah Aa Gym berikut ini.

(50) Kita bisa membesar, kita tidak tahu nutrisi apa yang kita perlukan untuk membesarkan tubuh kita.

(51) Allah tidak mengubah kaum yang tidak mau berubah.

(52) Oleh karena itu, kita harus punya keberanian. Berani mencoba dan berani memikul risiko.

(53) Jangan keseringan dipotret dipasang di mana-mana ya, kalau memasang potret anak boleh tidak di facebook, boleh, tidak ada larangan, tapi periksa hati kita. Jangan keseringan, yang wajar-wajar saja.

(54) Kita ingin anak kita dipuji terus, kalau orang muji anak kita jadi gimana, sudah gak robah, ya? Jangan berlebihan, itu bukan punya kita dan bukan bikinan kita. Kita boro-boro bikin anak, nggambar anak juga, jadi mirip babon, ya?

(55) Pesaing itu hamba Allah juga. Kita mau bersaing sama aja yang ngasih rejekinya Allah.

Pada data (50) ekuivalensi sebagai kohesi leksikal tampak pada paradigma membesar dan membesarkan; data (51) pada paradigma mengubah dan berubah; data (52) pada paradigma keberanian dan berani; data (53) pada paradigma dipasang dan memasang; data (54) pada paradigma dipuji dan muji, juga bikinan dan bikin; adapun data (55) pada paradigma pesaing dan bersaing. 


\section{Simpulan}

Berdasarkan uraian di atas, maka kesimpulanya adalah; Wujud kohesi gramatikal retorika dakwah Aa Gym mencakup referensi, substitusi, elipsis, dan konjungsi. Referensi merupakan salah satu jenis kohesi gramatikal yang berupa satuan lingual tertentu yang menunjuk satuan lingual lain yang mendahului atau mengikutinya. Substitusi merupakan salah satu kohesi gramatikal yang berupa penggantian satuan lingual tertentu atau yang telah disebut dengan satuan lingual lain. Elipsis adalah salah satu jenis kohesi gramatikal yang berupa penghilangan unsure atau konstituen tertentu yang telah disebutkan. Konjungsi merupakan salah satu jenis kohesi gramatikal yang dilakukan dengan cara menghubungkan unsur yang satu dengan yang lain. Wujud kohesi leksikal retorika dakwah Aa Gym mencakup repetisi atau pengulangan, sinonimi atau persamaan kata, antonimi atau lawan kata, hiponimi atau hubungan atas bawah, kolokasi atau sanding kata, dan ekuivalensi atau kesepadanan.

\section{Daftar Pustaka}

Aminuddin. 1995. Stilistika Pengantar Memahami Bahasa dalam Karya Sastra.Semarang: IKIP Press.

Faridl, Miftah. 1982. Pokok-pokok Ajaran Islam. Bandung: Perpuskaan Salman ITB.

Gymnastiar, Abdullah. 2003. Menjemput Rezeki dengan Berkah Kumpulan Tulisan Tausiyah. Jakarta: Republika.

Gymnastiar, Abdullah. 2005. Aa Gym Apa Adanya: Sebuah Qolbugrafi. Bandung: Khas MQ.

Ilham, Muhammad Arifin. 2003. Hakikat Zikir Jalan Taat Menuju Allah. Jakarta: Intuisi Press.

Mulyana. 2005. Kajian Wacana: Teori, Metode dan Aplikasi Prinsip-Prinsip Analisis Wacana. Yogyakarta: Tiara Wacana.

Pudiyono. 2008. “Wacana Pengajian 'Gemerlap Dunia Fana’ oleh K.H.A. 
Darmawan dalam dalam Di Ambang Fajar SCTV Analisis Mikro dan Makrostruktural" dalam Sumarlam. 2008. Teori dan Praktik Analisis Wacana. Surakarta: Pustaka Cakra.

Rani, Abdul, Bustanul Arifin, dan Martutik. 2006. Analisis Wacana Sebuah Kajian Bahasa dalam Pemakaian. Malang: Bayumedia Publishing. Saputra, Wahidin. 2002. Pengantar Ilmu Dakwah. Jakarta: Raja Grafindo Persada.

Subroto, D. Edi. 1992. Pengantar Metode Penelitian Linguistik Struktural. Surakarta: Sebelas Maret University Press.

Sudaryanto. 2002. Metode dan Aneka Teknik Analisis Bahasa. Yogyakarta: Duta Wacana University Press.

Suminto, Aqib. 1984. Problematika Dakwah. Jakarta: Pustaka Panjimas. Sutopo, H.B. 2002. Metodologi Penelitian Kualitatif Dasar Teori dan Terapannya dalam Penelitian. Surakarta: Sebelas Maret University Press.

Thaha, Idris (Ed.). 1997. Dakwah dan Politik Da'i Berjuta Umat K.H. Zainuddin MZ. Bandung: Mizan.

http://infoterbaruterbaru.blogspot.com/2013/11/kata-mutiara-yusufmansyur. html, diakses pada 26 Mei 2015.

http://indramukhtaroji.blogspot.com/2014/10/retorika-dalam-dakwah, diakses pada 26 Mei 2015. 